GOMES, RF; GONÇALVES, VP; ARRUDA, RS; SANTOS, LS. 2020. Multicategorical descriptors for creole genotypes of Amazon chicory (Eryngium foetidum). Horticultura Brasileira 38: 334-338.http://dx.doi.org/10.1590/S0102-053620200316

\title{
Multicategorical descriptors for creole genotypes of Amazon chicory (Eryngium foetidum)
}

\author{
Rafaelle F Gomes ${ }^{1} \mathbb{D}$; Viviane P Gonçalves ${ }^{1} \mathbb{D}$; Renata da S Arruda ${ }^{1} \mathbb{D}$; Lucas da S Santos ${ }^{2} \mathbb{D}$
}

${ }^{1}$ Universidade Federal Rural da Amazônia (UFRA), Capanema-PA, Brasil; rafaelle.fazzi@yahoo.com.br (author for correspondence);

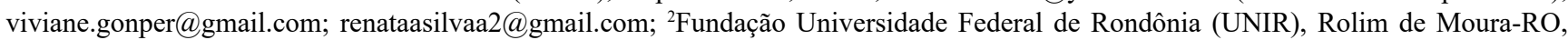
Brasil; lucasmelhorista@gmail.com

\begin{abstract}
The knowledge concerning genetic variability of creole genotypes by using morphological descriptors in species such as Amazon chicory is crucial to quantify local diversity and protect improved cultivars. Accordingly, this study aimed to propose multicategory leaf morphological descriptors for Amazon chicory species. To achieve that, an experiment was arranged in randomized block design with four repetitions. The treatments comprised eight creole genotypes of Amazon chicory, which were obtained from local producers' collection. The proposed multi-categorical descriptors are based on limb shape, leaf apex shape, leaf base shape, leaf margin, bract consistency, and bract margin traits. Once the multicategorical clustered data were obtained, they were transformed into a dissimilarity matrix. The limb shape presents dissimilarity, being either lanceolate or spatulate; as well as for leaf margin, which can be dentate or serrate. Thus, both limb shape and leaf margin constitute important qualitative descriptors for genetic diversity assessment and conservation for Amazon chicory, besides a recommended tool to be exploited in breeding programs.
\end{abstract}

Keywords: Pará chicory, landraces, genetic variability.

\section{RESUMO}

Descritores multicategóricos de genótipos crioulos de chicória da Amazônia (Eryngium foetidum)

Conhecer a variabilidade genética de genótipos crioulos, por meio do uso de descritores morfológicos em espécies como a chicória da Amazônia, é uma ferramenta imprescindível no processo de quantificação da diversidade de variedades locais e na proteção de cultivares melhoradas. Diante disso, objetivou-se propor descritores morfológicos multicategóricos foliares para a chicória da Amazônia. Para isso, foi realizado um experimento, utilizando o delineamento experimental em blocos ao acaso, com quatro repetições. Os tratamentos foram constituídos de oito genótipos crioulos de chicória da Amazônia, obtidos de coletas junto aos produtores. Os descritores multicategóricos propostos foram formato do limbo, formato do ápice foliar, formato da base foliar, tipo de margem foliar, consistência das brácteas e tipo de margem das brácteas. Após a obtenção dos dados multicategóricos em classes, os mesmos foram transformados em matriz de dissimilaridade. Observou-se que o formato do limbo apresentou variação, podendo ser do tipo lanceolado ou espatulado, assim como o tipo de margem foliar, que pode ser do tipo dentado ou serreado. Sendo assim, as características de formato do limbo e margens foliares se mostraram descritores qualitativos importantes na quantificação da diversidade genética, conservação e uso nos programas de melhoramento da chicória da Amazônia.

Palavras-chave: Chicória do Pará, landraces, variabilidade genética.

Received on April 14, 2020; accepted on July 27, 2020

$\mathrm{C}$ hicory (Eryngium foetidum) is a species belonging to the Apiaceae family, being classified as an unconventional vegetable. It is referenced as Pará chicory, Amazon chicory, coriander, nhambi or wild coriander, and in some countries as culantro (Gomes et al., 2013). Its origin comes back to tropical America and western India, being widely distributed in South Asia, the Pacific Islands, tropical Africa, and southern Europe (Paul et al., 2011). In Amazonian culture, it usually composes fish cuisine, seafood (the most popular "duck in tucupi") and tacacá in an equivalent manner to coriander uses. Moreover, the presence of bioactive compounds with medicinal properties, such as eryngial, is also another important characteristic to be exploited (Paul et al., 2011).

The demands about Amazon chicory studies related to its use and preservation were firstly reported by Cardoso \& Garcia (1997), which claimed the importance of consumption and conservation of genetic resources from vegetables available in the
Amazon, since important attributes are included, such as nutritional, ecological, agronomic, and cultural values, besides food security and employment availability.

According to Costa et al. (2015), to exploit genetic resources efficiently is essential the knowledge on the morphological aspects present in different populations of plants, as it greatly contributes to exploit genetic variability in breeding programs. Therefore, the morphological characterization enables the differentiation of creole Amazon 
chicory genotypes obtained by the producers, supporting their conservation in germplasm collections, basing on descriptors able to describe and categorize genetic materials. In general, leaves, flowers, fruits, and seeds are considered as morphological characters (Costa et al., 2015).

Additionally, Rodriguez et al. (2005) stated that the characterization of germplasm bank is a primary and important connection between conservation and use of plant genetic resources, in a manner that the local genetic variability is properly studied, preserved, and exploited in view of community benefits.

Morphological descriptors can be based on qualitative characters (characteristics obtained by observations), which are highly heritable and normally controlled by one or few genes, being not influenced by the environment. On the other hand, it can also be based on quantitative characters (characteristics obtained from measurements), which present polygenic inheritance and are highly influenced by the environment (Burle \& Oliveira, 2010).

As reported by Burle \& Oliveira (2010), the descriptors enable the differentiation between phenotypes, providing first estimates of variability within a plant collection. It is noteworthy that qualitative or multicategorical descriptors can be evaluated from nominal, ordinal, and binary scales.

Morphological descriptors are also essential at the final breeding stage, which includes cultivar protection under breeder ownership rights. The protection allows the breeder to hold exclusive licenses on the improved cultivar, stimulating continuous plant breeding. The first step for the protection of cultivars is composed of the tests of distinguishability, homogeneity, and stability (DHE) of cultivars. However, this requires the existence of previously established descriptors to prove the distinction, which for Amazon chicory does not yet exist or is not documented by the Ministry of Agriculture, Livestock, and Food Supply (MAPA).

Thus, by associating what is presented above with the current lack of morphological descriptors for this species, this work aimed to propose multicategorical leaf morphologicalbased descriptors for the Amazon chicory species.

\section{MATERIAL AND METHODS}

The experiment was conducted in an open field located at the experimental facility of the Universidade Federal Rural da Amazônia, Capanema, Pará (01 ${ }^{\circ} 11^{\prime} 45^{\prime} \mathrm{S}, 47^{\circ} 10^{\prime} 50^{\prime \prime} \mathrm{W}, 24 \mathrm{~m}$ altitude).

The trial was performed in a randomized blocks design, with eight treatments and four replications. The treatments consisted of eight genotypes of Amazon chicory. The plot presented 12 plants in total, with four plants as useful area.

The materials were collected from producers in eight municipalities of Pará and deposited at the Universidade Federal Rural da Amazônia collection, Campus Capanema (Table 1).

Seeds of Amazon chicory (five seeds per cell) were sown in polystyrene trays with 128 cells, filled with commercial substrate Tropstrato ${ }^{\circledR}$. After seedlings emergence, plantlets were thinned, remaining only one seedling per cell. At 61 days after sowing, the seedlings were transplanted in beds with dimensions $7 \times 1 \mathrm{~m}$, in a quadrangular spatial arrangement, using $20 \times 20 \mathrm{~cm}$ spacing.

Planting fertilization was carried out based on the soil chemical analysis and local recommendations for leaf vegetables cultivation, as previously described by Cravo et al. (2007). Daily irrigation and weekly weed control were the main cultural practices conducted. After 86 days of transplanting, plants that presented standard and uniform growth were selected to be evaluated.

The selection of qualitative (multicategorical) descriptors used in the present study was based on the previous consulting to the list of morphological descriptors for species belonging to Apiaceae family, developed by MAPA. Moreover, other chicoryrelated reports such as the previous study conducted by Mozumder et al. (2013) were considered.
Evaluations started at harvest time and the leaves were classified based on Vidal \& Vidal (2006) and Gonçalves \& Lorenzi (2011) reports. The multi-categorized descriptors for tested leaves were limb shape (lanceolate or spatulate); leaf apex shape (rounded or truncate); leaf base shape (attenuate or decurrent); leaf margin (dentate or serrate); bract margin (serrate or dentate); bract consistency (membranous or coriaceous).

The values per variable were assessed based on modal value, by considering the replicates in each treatment. After obtaining the multicategorical data in clusters, they were transformed into an estimate of genetic similarity $(\mathrm{SG}=\mathrm{Cjj}$ ') between all pairs of accessions, using the simple index of coincidence. Being: $(\mathrm{Cjj}=\mathrm{C} / \mathrm{C}+\mathrm{D})$, where $\mathrm{C}=$ values agreement, $\mathrm{D}=$ values disagreement. The similarity matrix was transformed into a genetic dissimilarity matrix (DG) from the complementary estimated similarity matrix $\left(\mathrm{DG}=1-\mathrm{Cjj}^{\prime}\right)$.

Grouping analysis for creole genotypes was accomplished by UPGMA hierarchical clustering method. Both validation and cut-off lines were determined by the cophenetic correlation coefficient (CCC) and Mojena (1977) test. To check the variability within each access, Tocher's grouping method was adopted. All statistical analyzes were performed via Genes (Cruz, 2013) software.

\section{RESULTS AND DISCUSSION}

After qualitative characterization of Amazon chicory genotypes (Table 2 ), via modal values resulting from multicategorical descriptors, we observed that the limb shape presents dissimilarity, being either lanceolate or spatulate; as well as for leaf margin, which can be dentate or serrate.

To verify whether multicategorical descriptors proposed for this species would be able to differentiate genotypes, a cluster analysis was performed using UPGMA method (Figure 1). To determine the dendrogram cut-off point, both cophenetic correlation coefficient and Mojena index were considered. 
The ideal cophenetic correlation coefficient is closest to 1 , which means that the distortion caused by grouping individuals by the UPGMA method is lower. In this study, the cophenetic correlation coefficient was considered high $(\mathrm{CCC}=0.86)$. Cophenetic correlations above 0.80 are recommended and demonstrate that the dendrogram does not present significant distortions.

The Mojena test indicated significance at $80.0 \%$ distance $(0.16)$. Thus, the cut-off point for dendrogram was set up to $80.0 \%$, which is under agreement with both Mojena index and high cophenetic correlation. Based on the dissimilarity matrix obtained by the index: Sii' $=(C / C+D)$, three distinct groups were observed in the dendrogram as a response to the UPGMA method.

The first cluster consists of landraces collected in Nova Timboteua, Santarém Novo, and São João de Pirabas regions.

Table 1. Origin of creole Amazon chicory genotypes. Capanema, UFRA, 2019.

\begin{tabular}{lll}
\hline Code & \multicolumn{1}{c}{ Origin } & \multicolumn{1}{c}{ Coordinates } \\
\hline CHIC-1 & Aurora-do-Pará & $02^{\circ} 07^{\prime} 45^{\prime \prime} \mathrm{S}, 47^{\circ} 33^{\prime} 22^{\prime \prime} \mathrm{W}$ \\
CHIC-2 & Bragança & $01^{\circ} 03^{\prime} 15^{\prime \prime} \mathrm{S}, 46^{\circ} 46^{\prime} 10^{\prime \prime} \mathrm{W}$ \\
CHIC-3 & Capanema & $01^{\circ} 11^{\prime} 45^{\prime \prime} \mathrm{S}, 47^{\circ} 10^{\prime} 51^{\prime \prime} \mathrm{W}$ \\
CHIC-4 & Capitão Poço & $01^{\circ} 44^{\prime} 54^{\prime \prime} \mathrm{S}, 47^{\circ} 03^{\prime} 42^{\prime \prime} \mathrm{W}$ \\
CHIC-5 & Nova Timboteua & $01^{\circ} 12^{\prime} 28^{\prime \prime} \mathrm{S}, 47^{\circ} 23^{\prime} 33^{\prime \prime} \mathrm{W}$ \\
CHIC-6 & Primavera & $00^{\circ} 56^{\prime} 36^{\prime \prime} \mathrm{S}, 47^{\circ} 07^{\prime} 06^{\prime \prime} \mathrm{W}$ \\
CHIC-7 & Santarém Novo & $00^{\circ} 55^{\prime} 45^{\prime \prime}, 47^{\circ} 23^{\prime} 55^{\prime \prime} \mathrm{W}$ \\
CHIC-8 & São João de Pirabas & $00^{\circ} 45^{\prime} 59^{\prime \prime} \mathrm{S}, 47^{\circ} 10^{\prime} 21^{\prime \prime} \mathrm{W}$ \\
\hline
\end{tabular}

Table 2. Groups and modal values for qualitative leaf descriptors applied to creole genotypes of Eryngium foetidum. Capanema, UFRA, 2019.

\begin{tabular}{lcccccccc}
\hline Genotypes & Location & $\begin{array}{c}\text { Number of } \\
\text { groups }^{1}\end{array}$ & LS & LAS LBS & LM & BC & BM \\
\hline CHIC-1 & Aurora do Pará & 2 & 1 & 1 & 1 & 1 & 1 & 1 \\
CHIC-2 & Bragança & 1 & 2 & 1 & 1 & 2 & 1 & 1 \\
CHIC-3 & Capanema & 4 & 2 & 1 & 1 & 2 & 1 & 1 \\
CHIC-4 & Capitão Poço & 3 & 2 & 1 & 1 & 2 & 1 & 1 \\
CHIC-5 & Nova Timboteua & 3 & 1 & 1 & 1 & 2 & 1 & 1 \\
CHIC-7 & Primavera & 2 & 2 & 1 & 1 & 2 & 1 & 1 \\
CHIC-8 & Santarém Novo & 2 & 1 & 1 & 1 & 2 & 1 & 1 \\
CHIC-6 & São J. de Pirabas & 3 & 1 & 1 & 1 & 2 & 1 & 1 \\
\hline
\end{tabular}

LS = limb shape (1: lanceolate; 2 : spatulate); LAS = leaf apex shape (1: rounded; 2 : truncate); LBS = leaf base shape (1: attenuate; 2 : decurrent); LM = leaf margin (1: dentate; 2 : serrate); $\mathrm{BC}=$ bract consistency (1: membranous; 2 : coriaceous); $\mathrm{BM}=$ bract margin (1: serrate; 2 : dentate). ${ }^{1}$ Clustering using the Tocher method.

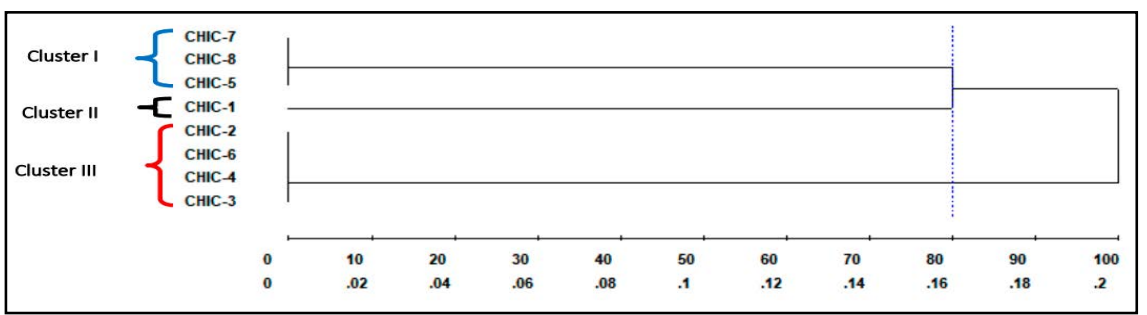

Figure 1. Dendrogram of genetic similarity in creole genotypes of Amazon chicory (Eryngium foetidum) based on six qualitative descriptors via UPGMA clustering method. Capanema, UFRA, 2019.

It is worth mentioning that there are no commercial Amazon chicory cultivars, thus the farmers produce their seeds themselves or purchase it from others. Therefore, the reason that such material is clustered comes through compelling evidence of seed exchange between local producers since these municipalities are close to each other.

The second group is composed of only one landrace, which was collected in Aurora do Pará (Figure $1)$. This municipality is the most remote geographically and presented different modal values for limb shape and leaf margin, as compared to other municipalities.

The third group is formed by landraces collected in Bragança, Capanema, Capitão Poço and Primavera (Figure 1). In the same way as for group I, the explanation for these materials being in the same cluster is the fact that the municipalities are near to each other and, thus, presenting a higher possibility of seed exchange between community producers.

To assess genetic variation within creole genotypes by descriptors technique, the cluster analysis was performed via Tocher' method, in which all plants considered as creole genotype were evaluated. The generated clusters demonstrate the formation of distinct groups within the genotypes for each of the eight genotypes, except for Bragança, which presented only one cluster (Table 2).

The formation of distinct groups within the creole genotype evidences that these materials are not stable, a fact that can be explained by constant practice of seeds exchange between producers, besides the absence of commercial Amazon chicory cultivars. It is worth noting that the creole genotype obtained in Bragança did not present substantial variation in analyzed plants, which seems that this material can be a single pure line and, therefore, more stable.

The diversity presented by the formation of clusters allows us to infer that the leaf morphological characters are able to differentiate important traits present in Amazon chicory genotypes. These are the first descriptors proposed for Amazon chicory and it is expected 


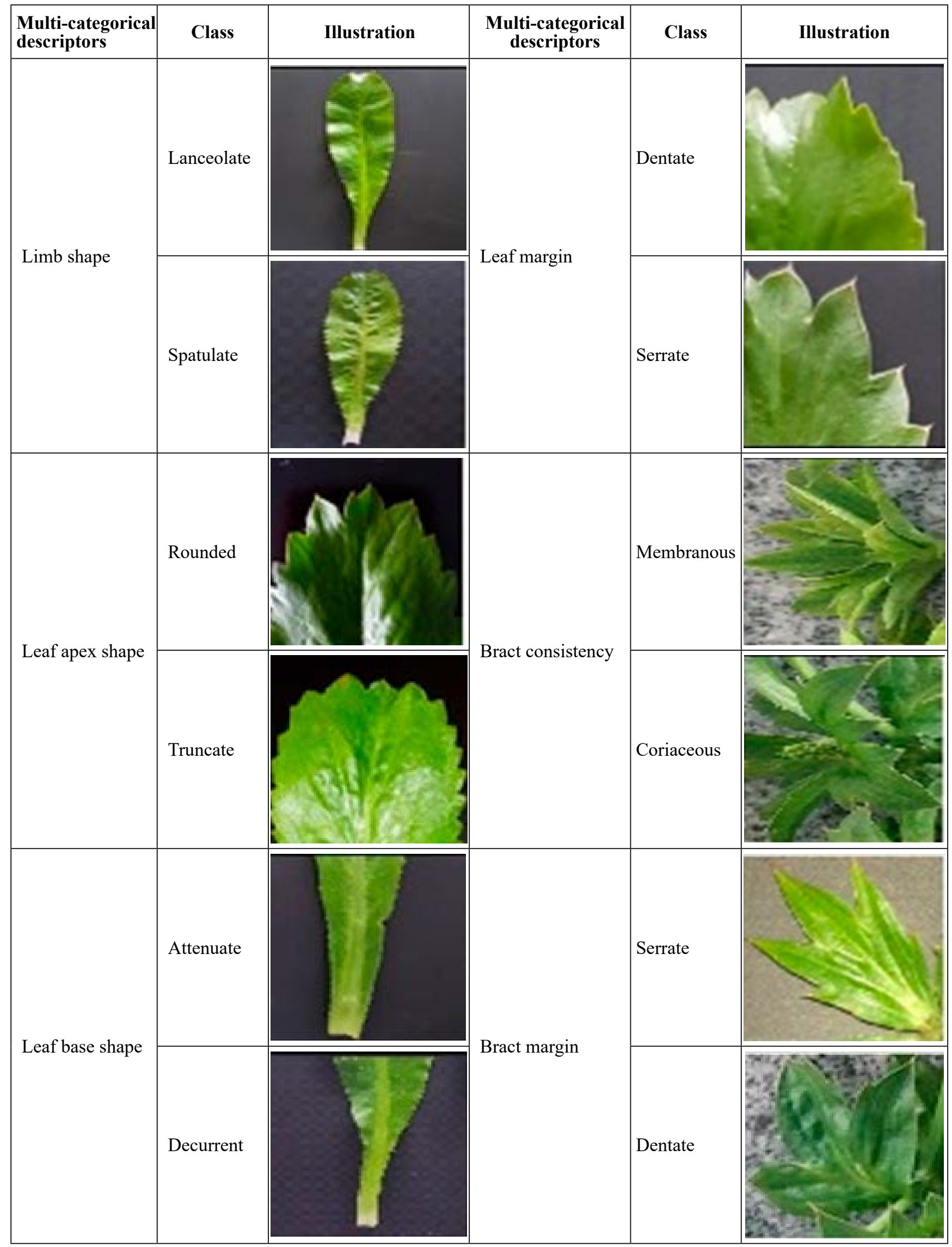

Chart 1. Multicategorical leaf descriptors for Eryngium foetidum. Capanema, UFRA, 2019. 
that they will be important bases for both crop breeding and cultivars protection programs.

The main objectives of a crop breeding program include, certainly, the characters linked to leaves traits, since this is the main energy source of the plant. Thus, the multi-categorized leaf descriptors proposed for Amazon chicory are summarized in Chart 1 and can be used by researchers.

The leaf descriptors proposed for Amazon chicory allowed the characterization and differentiation of creole genotypes evaluated in the present study, thus highlighting the limb shape and leaf base shape as the most important qualitative descriptors for Amazon chicory.

\section{ACKNOWLEDGMENTS}

The authors are grateful to the
Scientific Initiation Program of the Universidade Federal Rural da Amazônia (UFRA-PROIC) for research support and scholarships.

\section{REFERENCES}

BURLE, ML; OLIVEIRA, MSP. 2010. Manual de curadores de germoplasma vegetal: caracterização morfológica. Brasília: Embrapa Recursos Genéticos e Biotecnologia. 15p.

CARDOSO, MO; GARCIA, LC. 1997. Hortaliças não convencionais da Amazônia. Manaus: Embrapa CPAA. 140p.

COSTA, LV; BENTES, JLS; LOPES, MTG; ALVES, SRM; VIANA JÚNIOR, JM. 2015. Caracterização de acessos de pimentas do Amazonas. Horticultura Brasileira 33: 290298.

CRAVO, SM; VIÉGAS, IJM; BRASIL, EC. 2007. Recomendações de adubação e calagem para o Estado do Pará. 1 ed. Belém: Embrapa Amazônia Oriental. 262 p.

CRUZ, CD. 2013. GENES - A software package for analysis in experimental statistics and quantitative genetics. Acta Scientiarum Agronomy 35: 271-276.
GOMES, RF; SILVA, JP; GUSMÃO, SAL; SOUZA, GT. 2013. Produção de chicória da Amazônia cultivada sob densidades de cultivo e poda do pendão floral. Revista Caatinga 26: 9-14.

GONÇALVES, EG; LORENZI, H. 2011. Morfologia vegetal: organografia $e$ dicionário ilustrativo de morfologia das plantas vasculares. 2ed. São Paulo: Instituto Plantarum. 512p.

MOJENA, R. 1977. Hierarchical grouping methods and stopping rules: an evaluation. The Computer Journal 20: 359-363.

MOZUMDER, SN; RAHAMAN, MM; HOSSAIN, MM. 2013. Variability and character association in Bangladhonia (Eryngium foetidum L.). Journal Agricultural Research 38 (1): 77-84.

PAUL, JHA; SEAFORTH, CE; TIKASINGH, T. 2011. Eryngium foetidum L.: A review. Fitoterapia 82: 302-308.

RODRÍGUEZ, VM; CARTEA, ME; PADILLA, G; VELASCO, P; ORDÁS, A. 2005. The nabicol: a horticultural crop in northwestern Spain. Euphytica 142: 237-246.

VIDAL, WN; VIDAL, MRR. 2006. Botânica organográfica: Quadros sinóticos ilustrativos de fanerógamas. 4. ed. rev. ampl. Viçosa: UFV. 124p. 